\title{
Palaeostages of the Caspian Sea as a set of regional benchmark tests for the evaluation of climate model simulations
}

\begin{abstract}
A. Kislov ${ }^{1}$, A. Panin ${ }^{2}$, and P. Toropov ${ }^{1}$
${ }^{1}$ Lomonosov Moscow State University, Faculty of Geography, Department of Meteorology \& Climatology, Lenin Gory, 1, 119991, Moscow, Russia

${ }^{2}$ Lomonosov Moscow State University, Faculty of Geography, Department of Geomorphology \& Palaeogeography, Lenin Gory, 1, 119991, Moscow, Russia
\end{abstract}

Received: 23 September 2012 - Accepted: 3 October 2012 - Published: 10 October 2012

Correspondence to: A. Kislov (avkislov@mail.ru)

Published by Copernicus Publications on behalf of the European Geosciences Union.

\section{8, 5053-5081, 2012}

Palaeostages of the Caspian Sea as a set of regional benschmark tests

A. Kislov et al.

\section{Title Page}

Abstract Introduction

Conclusions References
Tables

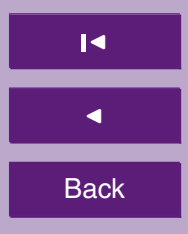

Full Screen / Esc

Printer-friendly Version

Interactive Discussion
Figures

$>1$

D

Close 


\section{Abstract}

Oscillations of the level of the Caspian Sea (CS) primarily stem from variations in runoff from the Volga River. Therefore, changes in the level of the CS can be used to assess the ability of climate models to reproduce the water budget over the East Euro5 pean Plain. We compare observed or reconstructed CS level positions during the Last Glacial Maximum (LGM), Holocene and modern periods with the CS level positions calculated based on simulations in experiments using the CMIP5/PMIP3 protocol. The proxy dataset comprises a number of detailed maps of the CS for the main regression stages and transgression stages during the last 30 ka together with information about 10 sea-level positions. The results show poor correspondence between the model simulations of decadal- and centennial-scale level oscillations and proxy reconstructions. We propose that such discrepancies can be caused by insufficient sensitivity of the climate models used. The modelled data could be verified based on how well the models simulated the sharp decrease of the Volga River runoff during the LGM, which caused a 15 large decline of the CS level.

\section{Introduction}

Evaluating the models used for prediction is important for identifying uncertainties in prediction and guiding priorities for model development. Traditionally, a set of benchmark tests for climate models are used that are based on time series observed during the last $\sim 150 \mathrm{yr}$. These tests are not completely adequate because these data are used to verify all units of climate models. From this perspective, climate models are implicitly tuned to the current climatic conditions. Therefore, developing an additional set of benchmark tests (independent of the current climate conditions) is very important. These tests could be developed using either palaeodata or meteorological information from other planets. The latter data are not suitable to the necessary extent, but the great success of palaeodata reconstructions has established a
8, 5053-5081, 2012

Palaeostages of the Caspian Sea as a set of regional benschmark tests

A. Kislov et al.

Title Page

Abstract Introduction

Conclusions

Tables

References

Figures

14

$\rightarrow 1$

4

Back

Close

Full Screen / Esc

Printer-friendly Version

Interactive Discussion

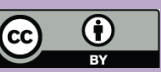


foundation for the use of these data for model validation. At the present time, several climate-simulation projects belonging to Coupled Model Intercomparison Project, Phase 5 (http://cmip-pcmdi.Inl.gov/cmip5/), and Palaeoclimate Modelling Intercomparison Project, Phase 3 (http://pmip3.Isce.ipsl.fr/) (CMIP5/PMIP3) and have been focused 5 on such time periods as the last millennium, Mid-Holocene, and the Last Glacial Maximum (LGM). Temperature and precipitation values are commonly used for comparison.

This paper proposes a set of benchmark tests designed to quantify the performance of the simulated water budget (the balance between inflow and outflow components) of the East European Plain (EEP). The tests are designed to assess the ability of models 10 to reproduce the observed regional-scale changes of water fluxes on different time scales (interannual, decadal, and centenarian) under the different boundary conditions and parameters of the Late Pleistocene, Holocene and last millennium. Water-budget changes over the EEP are reflected by the fluctuations of the Caspian Sea (CS) area and level, which collects precipitation from the majority of the EEP.

15 Such tests are important for assessing model quality because model data are more reliable over vast flat territories compared to complex land surfaces (mountains, archipelagos of islands, etc.). From this perspective, models must first be validated over such "idealised" areas. In mid-range latitudes, there are several such areas (taking into account the possible areas' size and flat topography). These areas are the EEP, the Great Plains, the Western Siberia Plain and Australian deserts. The EEP is the most convenient area for detecting the water-budget changes induced by climate changes because most of the EEP area drains into a closed lake (the CS). Hence, the CS level change is the integral indicator of the water-budget conditions of the EEP. The huge size of the water body allows more convenient quantification of the changes compared with other lakes, such as, for example, Lake Chad.

Precise reconstructions and dating have demonstrated that during the Late Pleistocene and postglacial periods, the CS fluctuated between regression and transgression stages. Sometimes, the CS overflowed into the Black Sea, and these water bodies periodically coalesced. These events occurred in response to the regional-scale
8, 5053-5081, 2012

\section{Palaeostages of the Caspian Sea as a set of regional benschmark tests}

A. Kislov et al.

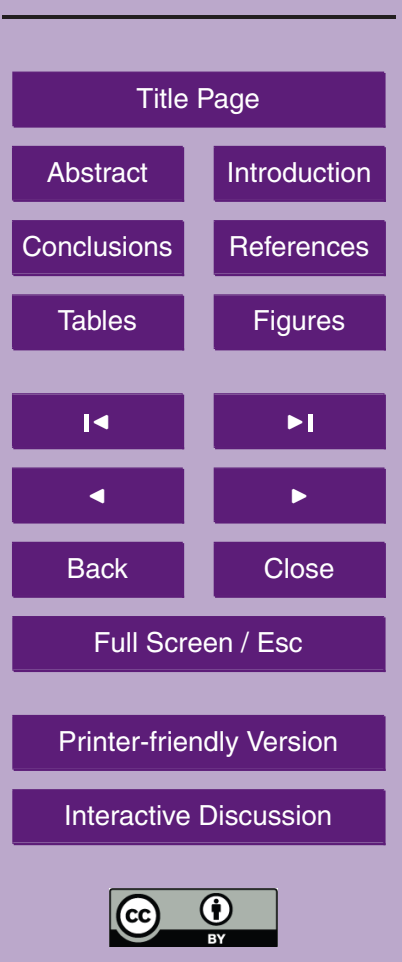


water-budget change. Variations of these components can be calculated using climate models. Therefore, we were able to use a model-data comparison to test simulated variations of the river runoff against reconstructed time-series of the CS level changes.

The focus of this study is the assessment of how well PMIP3 climate models simu5 late the CS level changes during different conditions of the past and how a system of benchmark datasets can be based on such simulations. The water budget of the CS, current changes and its reproduction using models are described in Sects. 2 and 3. The evolution of the CS basin (its level and area) is presented in Sect. 4. The CS during the Mid-Holocene and LGM is analysed in Sect. 5. Section 6 addresses the origin 10 of large CS transgressive stages. Section 7 consists of conclusions.

\section{The Caspian Sea, changes in its level and the connections of such changes to river-runoff fluctuations}

The CS is situated in a semi-arid area between southern Russia, Kazakhstan, Turkmenistan, Iran and Azerbaijan (36-47 $\left.\mathrm{N}, 47-54^{\circ} \mathrm{E}\right)$. The CS is a closed basin without 15 any outlet. The mean CS sea level lies approximately $27 \mathrm{~m}$ below the mean sea level of the oceans ( -25 to $-29 \mathrm{~m}$ during the last $150 \mathrm{yr}$ ). The main water source of the CS is the Volga River, whose catchment area reaches well into the humid mid-latitudes. The water inflow is compensated by evaporation over the CS itself. The CS lies in an area of strong tectonic activity (Allen et al., 2004). However, for the post-LGM time, tec-

tonic impacts on sea-level changes do not have to be taken into account because there have been no tectonic deformations of the Holocene shorelines, and only low-degree deformations of the Khvalynian (the end of the Late Pleistocene) shorelines have been detected (Rychagov, 1997).

The CS level has experienced high fluctuations during the period of instrumental ob25 servations, with a fast drop of $1.7 \mathrm{~m}$ during the $1930 \mathrm{~s}$, a further $1.2 \mathrm{~m}$ drop in 1977 and then a significant rise of $2.5 \mathrm{~m}$ between 1978 and 1995 (Kaplin and Selivanov, 1995). This study helps to understand the important processes that lead to these changes
$8,5053-5081,2012$

\section{Palaeostages of the Caspian Sea as a set of regional benschmark tests}

A. Kislov et al.

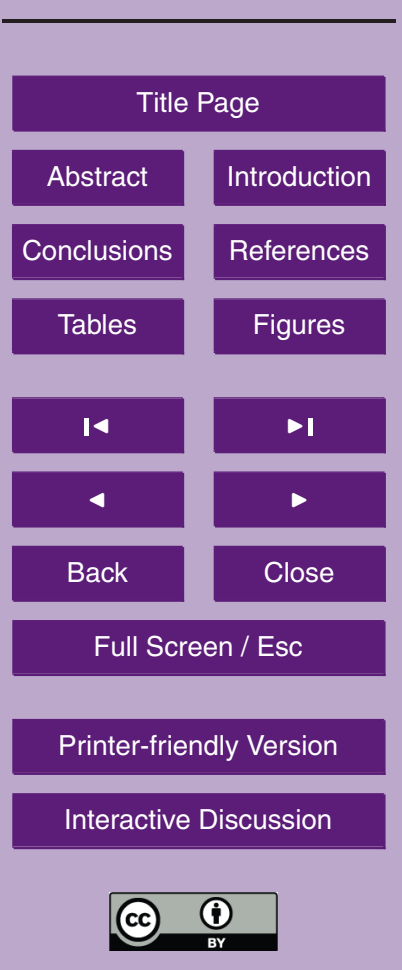


in the CS level. An inspection of the annual water-balance equation for the CS can provide some clues:

$$
\frac{\mathrm{d} V}{\mathrm{~d} t}=Q_{\text {in }}-Q_{\text {out }} \text {. }
$$

This equation denotes how the annual CS volume $(V)$ increment is determined by the 5 balance between inflow and outflow components. The $Q_{\text {in }}$ is practically fully determined by the total river inflow (the annual runoff is $274 \mathrm{~km}^{3}$ ) because the contribution of the subsurface runoff into the sea is less than $20 \%$. A total of $80 \%$ of the river discharge comes from the Volga River. We can consider $Q_{\text {in }} \approx k Q$, where $k \approx 0.7$. Additionally, $Q_{\text {out }}=f_{0}(E-P)$, where $P$ and $E$ are the precipitation and evaporation per unit of sea

10 surface, respectively, and $f_{0}$ is the average area of the sea corresponding to the current range of the level positions. Observations of the single components are as follows (Golitsyn and Panin, 1989): $Q_{\text {in }} \approx 75 \mathrm{~cm} \mathrm{yr}^{-1}$ and $(E-P) \approx 75 \mathrm{~cm} \mathrm{yr}^{-1}$.

Over the long term, we can describe the relationship between the sea level and status of climate, assuming that the closed lake (sea) is in hydrologic equilibrium with 15 the climate conditions. A steady-state approach $\left(Q_{\text {in }}=Q_{\text {out }}\right)$ allows calculations of the changes of the sea surface area (and level changes taking into account the lake size, bathymetry and surrounding topography) in each climate time period based on links between variations in sea level and water-budget components. Figure 1 depicts the connection of the CS level with annual values of river runoff and $(P-E)$ over the sea 20 surface. Such an approach was used to assess the Caspian Sea (and Black Sea) level response to the large climate perturbations of the late Pleistocene and the midHolocene (Kislov and Toropov, 2006, 2011).

Now, we reach a time-dependent task. We consider a simplified model demonstrating that the decadal variations of the CS level are primarily balanced by the Volga River 25 runoff changes. Taking into account small changes of $V$, we consider $V \approx f_{0} \mathrm{~d} h, \mathrm{~d} h \approx$ $h-h_{0}$. The annual CS volume increment is the residual of mainly two large quantities, river runoff (practically, the Volga River runoff) and $E$, while the remainder is small compared to these two large quantities but is comparable to the increment itself.
8, 5053-5081, 2012

Palaeostages of the Caspian Sea as a set of regional benschmark tests

A. Kislov et al.

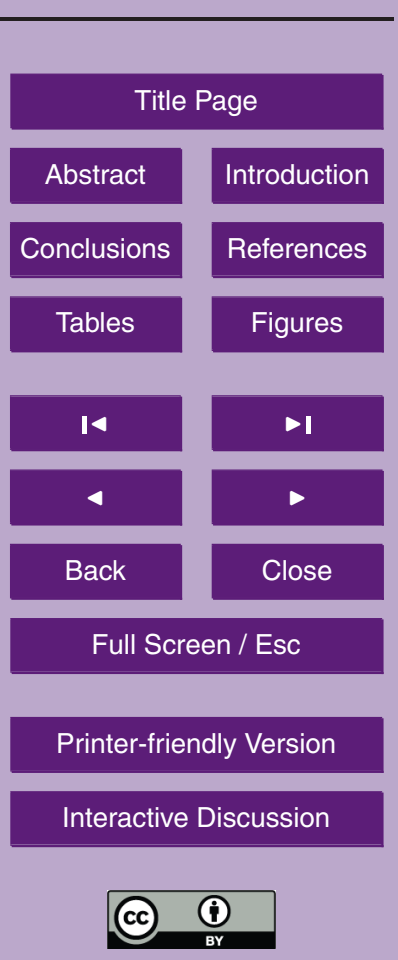


An analysis of the time series of the observed data shows that the $Q_{\text {out }}$ has changed randomly (Mikhailov and Povalishnikova, 1998). The standard deviation (std in units of $\mathrm{m} \mathrm{yr}^{-1}$ ) of the runoff fluctuations $(0.16)$ is much greater than the std of the $Q_{\text {out }}$ fluctuations (0.08) (Golitsin et al., 1998). We can connect the average values of $Q_{\text {out }}$ and 5 the average runoff of the Volga River as follows: $Q_{\text {out }}=\mu Q_{0}$, where $\mu \approx k$; otherwise, the $Q_{\text {in }}$ has to be considerably different from the $Q_{\text {out }}$. Thus, the simplified form of the budget equation is as follows:

$\frac{\mathrm{d} h}{\mathrm{~d} t}=\frac{k Q_{0}}{f_{0}}\left(\frac{Q-Q_{0}}{Q_{0}}\right)$

Hence,

${ }_{10}^{h} \mathrm{~d} h \sim \int_{h_{0}}^{t} \frac{Q-Q_{0}}{Q_{0}} \mathrm{~d} t$

Or, using interannual level changes and annually averaged values of the runoff, we calculate the following relation:

$h_{i}-h_{0} \sim \sum_{i} \frac{Q_{i}-Q_{0}}{Q_{0}}$

Therefore, the level change depends on the accumulated departures. This so-called

"cumulative curve" also depends on the period from which the mean value is calculated. This approach is helpful to establish the relation between the EEP water-budget variations (in response to climate change) and the CS level changes.

In Fig. 2, the cumulative curve of the Volga River runoff is shown together with the CS level changes. High correlations occur, especially for long intervals with large level changes. This fact demonstrates that, indeed, long-term variations of the CS level are due to river-runoff changes. For shorter periods, the evaporation variability over the CS itself has clear impacts (Arpe et al., 2012).

\section{8}

\section{$8,5053-5081,2012$}

\section{Palaeostages of the Caspian Sea as a set of regional benschmark tests}

A. Kislov et al.
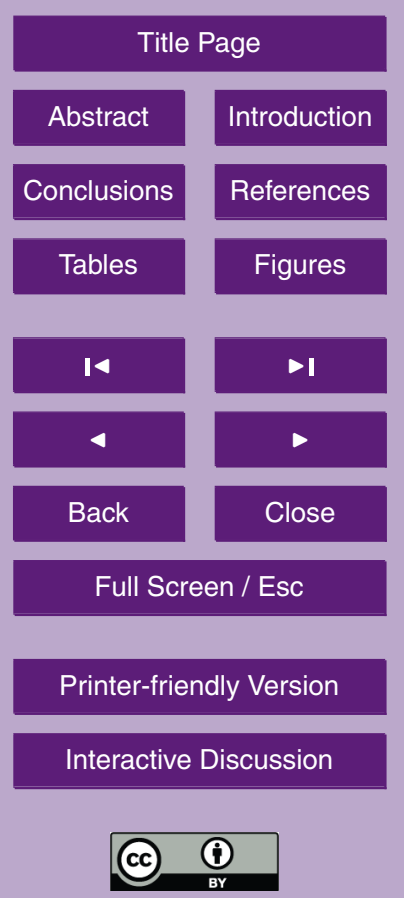
Therefore, we can conclude that the large transgressive and regressive stages of the CS could be used as a set of benchmark tests to verify a simulated water budget of the EEP. We propose a method of verification based on a comparison of the cumulative curves of simulated Volga River runoff variations and observed (or reconstructed) CS

5 level changes. In the next sections, we use such a method to compare simulated and observed data for both current climate changes and palaeoclimate events.

\section{Current Caspian Sea level changes and the possibility of reproducing such changes using several CMIP5 models}

By comparing the current temporal variability of the CS level and the Volga River dis10 charge, it becomes apparent (Fig. 2) that the CS level variability can mainly be assigned to the variability of the Volga River discharge, which primarily results from the variability of the precipitation over the river's catchment area (Rodionov, 1994; Mikhailov and Povalishnikova, 1998). In this section, we use output data from the CMIP5/PMIP3 experiments from the three models for which suitable data are currently available. We 15 use data from the following models: the MIROC-ESM (Watanabe et al., 2011) (hereafter miroc), the GISS Model E (Schmidt et al., 2006) (hereafter giss) and the CNRMCM5.1 (Voldoire et al., 2012) (hereafter cnrn). The output data (with different timeseries lengths) from these models were used to generate a scenario of Volga River runoff changes.

20 We compare the Volga River runoff volumes as simulated using climate models that reproduce the current climate changes and the observed Volga River runoff volumes. The ratio of the std of the runoff fluctuations to the std of the $Q_{\text {out }}$ fluctuations is 2.4 and 4.3 for the models giss and miroc, respectively. This finding confirms that the introduced method of a cumulative curve can be used to interpret modelled data. However, the simulated cumulative curves are too small to simulate the observed variations of the runoff (Fig. 3). This result indicates that the models cannot reproduce the observed CS level changes $\pm 1.5 \mathrm{~m}$ (Fig. $2 \mathrm{a}$ ). With respect to the phase

\section{$8,5053-5081,2012$}

\section{Palaeostages of the Caspian Sea as a set of regional benschmark tests}

A. Kislov et al.

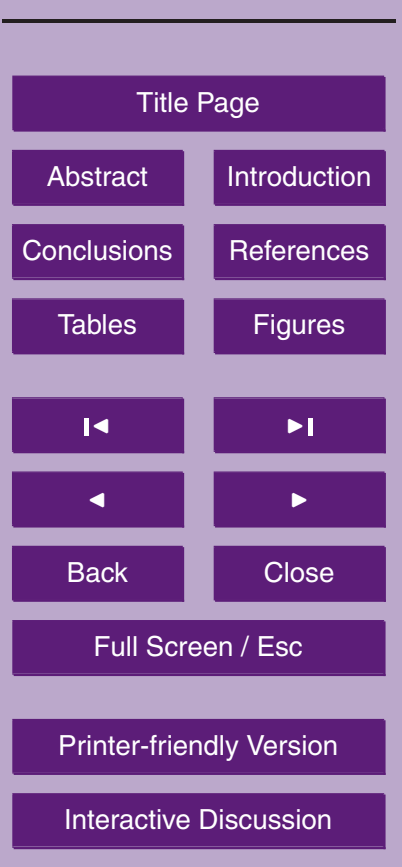


of the oscillation, we can conclude that only the cnrn data are "in phase" with the observed data but that the amplitude of change differs.

We can conclude that the explored CMIP5 models are not sensitive enough to reproduce the current CS level changes. The same result was noted based on models 5 belonging to PMIP1 (e.g. Kislov and Toropov, 2006), but Arpy and Leroy (2007) indicated (although their results were statistically insignificant) that the ECHAM5 model simulated the CS level changes. However, it could be hoped that large oscillations of the CS level changes (during the palaeo-climate transgressive and regressive stages of the CS) could be reproduced using models.

\section{Main stages of the Caspian Sea in the Late Pleistocene and the Holocene}

During the last $100 \mathrm{ka}$, the CS level experienced a complex pattern of cyclic transgressive-regressive stages of variable durations and amplitudes. The succession and relative age of the major stages are well established, although the absolute ages of the pre-Holocene stages are still under debate (Table 1). The level height is reliably established for high (transgressive) stages because it is exhibited by ancient shorelines. Estimations of the level drops during low (regressive) stages are more variable. The total range of the sea level change was more than $100 \mathrm{~m}$ in the Late Pleistocene and approximately $20 \mathrm{~m}$ in the Holocene.

The key chronological problem under discussion is the age of the Early Khvalynian 20 stage that is ranked as the highest Pleistocene transgression of the CS. The traditional view is that this transgression corresponds to the Early Valdai (Early Vistulian) glaciation (OIS-4) (Varuschenko et al., 1987; Rychagov, 1997, etc.). An alternative view relates this transgression with post-LGM time (end of OIS-2) (Svitoch, 2003; Chepalyga, 2007; etc.). In the last decade, data from borehole sections in the shallow Northhighstand to the Middle Valdai climate amelioration (OIS-3) (Bezrodnykh et al., 2004: Sorokin, 2011). All researchers consider the LGM as the time of a deep regression

8, 5053-5081, 2012

\section{Palaeostages of the Caspian Sea as a set of regional benschmark tests}

A. Kislov et al.

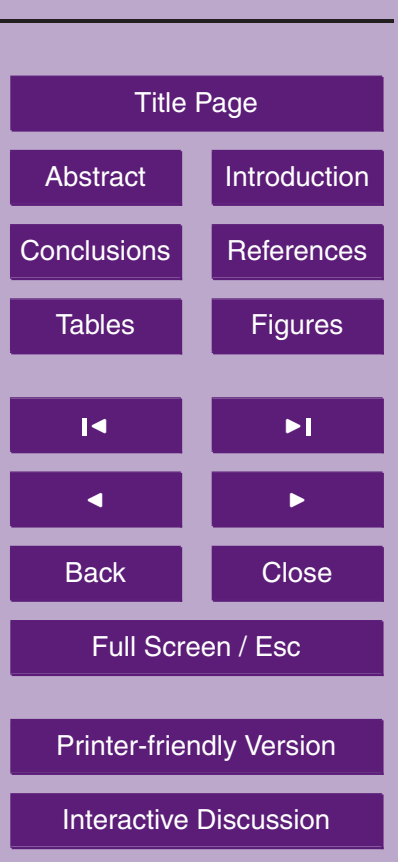


of the CS, but depending on how the Early Khvalynian highstand is dated, the LGM lowstand is referred to either as the Enotaevkian regression that divides the Early Khvalynian and Late Khvalynian stages (Varuschenko et al., 1987; Rychagov, 1997; Bezrodnykh et al., 2004; Sorokin, 2011) or as the Atelian regression that precedes the

5 Early Khvalynian highstand (Svitoch, 2003; Chepalyga, 2007). In our view, the most reliable and supported by recently obtained geological data is the first scenario, with the Early Khvalynian high stage occurring in the late MIS 3 and the LGM associated with the Enotaevkian regression (see Table 1, bold numbers).

Whichever chronological scenario is used, the Valdaian cold epoch (MIS 2-4) 10 demonstrates a much higher amplitude of CS level changes compared to the Holocene (MIS 1) (Table 1). Due to the rather gentle slope of the bottom of the CS, the area occupied by the CS varied 4-fold during the MIS 3 - MIS 2 epochs (Fig. 4). A new estimation of the stage $v s$. area function (Panin and Selezneva, 2011) provides the following values of the CS area $\left(A_{S}\right)$ and its ratio to the catchment area ${ }_{15}\left(A_{\mathrm{C}}\right): A_{\mathrm{S}}+A_{\mathrm{C}}=3270 \times 10^{3} \mathrm{~km}^{2}$. At the modern stage of $-27 \mathrm{~m}$ a.s.l., the $\mathrm{CS}$ area is $424 \times 10^{3} \mathrm{~km}^{2}$, and $A_{\mathrm{C}} / A_{\mathrm{S}}=6.7$. At the highest Pleistocene stage of $+48 \mathrm{~m}$ a.s.l., which was reached during the Early Khvalynian transgression, the CS occupied an area of $930 \times 10^{3} \mathrm{~km}^{2}$, which yields an $A_{\mathrm{C}} / A_{\mathrm{S}}$ ratio of 2.5 . The Early Khvalynian high stage at 0 ma.s.l., with a sea area of $700 \times 10^{3} \mathrm{~km}^{2}$, occurred under an $A_{\mathrm{C}} / A_{\mathrm{S}}$ ratio of 3.7 . 20 A stage of -50 ma.s.I., which is representative both of the Enotaevkian (LGM) and Mangyshlakian (Younger Dryas) regression stages, is associated with a sea area of $234 \times 10^{3} \mathrm{~km}^{2}$ and an $A_{C} / A_{S}$ ratio of 13.0 . The many-fold alterations of the $\mathrm{A}_{C} / \mathrm{A}_{S}$ ratio most likely reflect a high degree of hydrological changes over the CS catchment during MIS 2 - MIS 3. Reproduction of these changes may serve as one criterion for the 25 evaluation of palaeoclimate modelling results.
8, 5053-5081, 2012

Palaeostages of the Caspian Sea as a set of regional benschmark tests

A. Kislov et al.

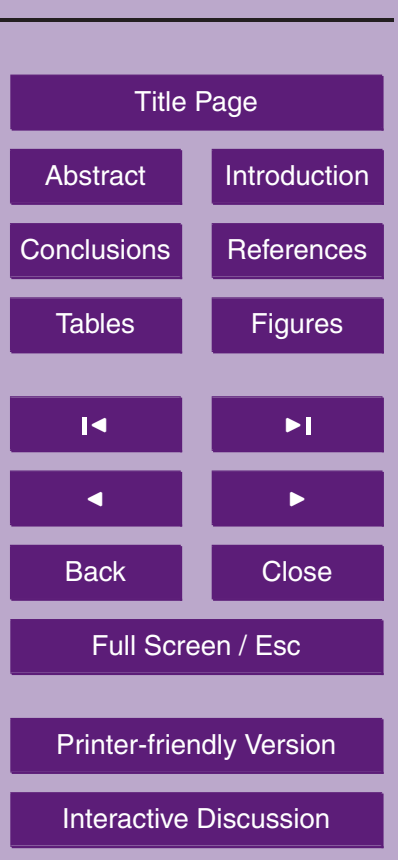




\section{Simulation of the Caspian Sea behaviour during the Last Glacial Maximum and Mid-Holocene}

In this section, we analyse the conditions of the Last Glacial Maximum (LGM). The first question is how well PMIP3 models simulate the regression stage of the Caspian

5 Sea at the moment of the LGM. This problem was carefully investigated using the PMIP1 data set (Kislov and Toropov, 2007). At $21 \mathrm{ka} \mathrm{BP,} \mathrm{the} \mathrm{total} \mathrm{river} \mathrm{runoff} \mathrm{to} \mathrm{the}$ CS was substantially less $(\sim 50 \%)$ than the runoff today. The relative contribution of Volga River runoff was $72 \%$. Based on the connection diagram (Fig. 1), we calculated a substantial drop in the CS level $(\sim 50 \mathrm{~m})$, which means that the relative decrease of 10 the CS area was $50 \%$. This result is important in light of the problem of time correlation among various palaeoevents belonging to different regions and different spatial scales. Hence, these changes in sea level reflect the planetary-scale climate forcing. This finding lends credence to the idea of a connection between the deep regression states of the CS and the mature stages of the Late Quaternary glacial/cooling/drying planetary 15 events. Moreover, several last huge regression stages occurred simultaneously with Late Quaternary glacial planetary events (Kislov and Toropov, 2011).

In this section, we used output data from the LGM experiment of the PMIP3 using the miroc model for which suitable data are currently available. These data were used to estimate the main water-budget components of the Volga River catchment (see Table 2). The river runoff was substantially decreased ( 30\%) compared to present values. Simultaneously, a substantial drop in the CS level was reproduced.

The data from miroc were used to study decadal-scale changes of the runoff. We again used the introduced earlier approach because the main contribution to the CS level variations was again determined by the Volga runoff variations (the ratio of stds is 25 approximately 1.5 based on the miroc data). The cumulative curve for the LGM (Fig. 5) varied over a wider range compared to modern data (Fig. 3), but in general, the behaviour of fluctuations was similar in spite of sharp contrasts in background climatic conditions.

\section{Palaeostages of the Caspian Sea as a set of regional benschmark tests}

A. Kislov et al.

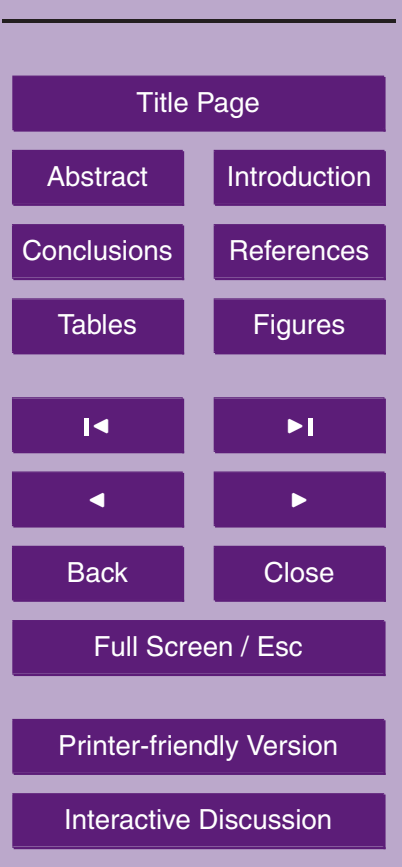


We used output from the Mid-Holocene (6 ka BP) CMIP5/PMIP3 experiment from the two models for which suitable data are currently available. The data from the miroc simulations were used to estimate the main water-budget components of the Volga River catchment (see Table 3). The modern averaged position of the CS level has 5 not changed since the Mid-Holocene. However, during the last ten thousand years, there were several epochs of transgressions and regressions (the Makhachkalanian regression and the New-Caspian transgressions; see Table 1). The CS level anomalies ranged between -9 and $+7 \mathrm{~m}$ (see Table 1 ).

We studied time-series of the water-budget components and established again that 10 the ratio of stds is high (11.1 on the basis of the miroc data). This result indicates that the method of cumulative curves can be used for interpretation. These curves for the Mid-Holocene (Fig. 6) look similar to modern curves (Fig. 3), i.e. the variance of decadal-scale fluctuations was the same during the Mid-Holocene and modern times. However, the simulated time-series are too short to estimate the possibility of simulat15 ing centennial-scale oscillations.

\section{On the origin of the Caspian Sea transgressive stages}

The highest Pleistocene transgression of the CS was the Early Khvalynian stage (Table 1). The marine data are supported by the results of the investigation of river-runoff changes. The results support a strong climate-driven increase of river runoff in the 20 central and southern parts of the EEP after the LGM (Panin and Sidorchuk, 2006; Sidorchuk et al., 2009). Numerous traces of large palaeochannels exist in river valleys that require channel-forming discharges several times as great as modern discharges for their development. Palaeochannels have been radiocarbon dated to 13-18 ka BP (cal), i.e. from the end of the Late Pleniglacial to the Late Glacial. Empirical relationships between the channel dimensions and river discharges that take proper account of seasonal variations of water flow provide estimations of the annual runoff from the Volga River catchment in the Late Glacial at 500 (Sidorchuk et al., 2009) $-580 \mathrm{~km}^{3} \mathrm{yr}^{-1}$

\section{3}

8, 5053-5081, 2012

Palaeostages of the Caspian Sea as a set of regional benschmark tests

A. Kislov et al.

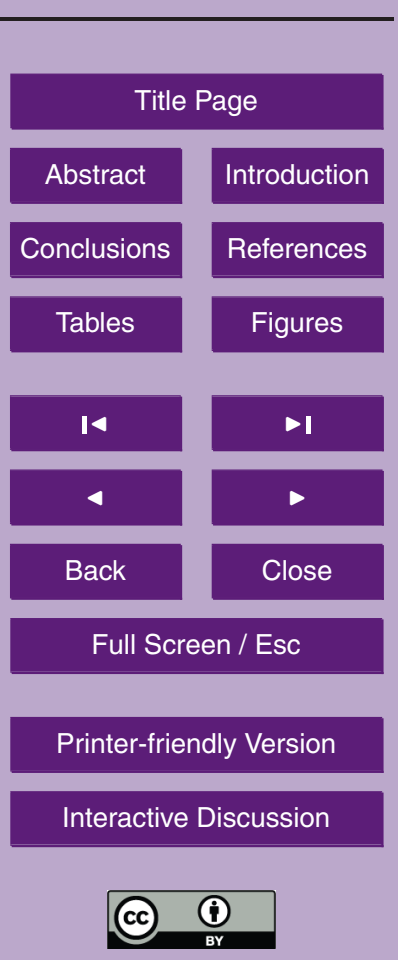


(Panin and Sidorchuk, 2006), i.e. 2.0-2.3 times as much as the present-day Volga River runoff at Volgograd (top of the river delta). Taking into account the rest of the catchment, the annual river runoff into the Caspian Sea can be estimated at $550-650 \mathrm{~km}^{3}$. Under a modern $(P-E)$ value over the sea surface of $\sim 800 \mathrm{~mm} \mathrm{yr}^{-1}$, this runoff is enough 5 to maintain the CS at its Late Khvalynian stage ( 0 m a.s.I.), while under lower $(P-E)$ values, this runoff volume may account for the CS Early Khvalynian stage (+48 m a.s.I.) (cf. Fig. 1). This scenario requires additional atmospheric water input from the catchment. However, such a high river runoff in the Late Glacial is not reproduced by climate models (Kislov and Toropov, 2006, 2007). The aforementioned modelling results have 10 shown that during warm periods such as the Mid-Holocene and the Allerod event, the simulated river runoff did not increase sufficiently to generate a huge CS transgression leading to water overflow into the Black Sea, as is proposed for post-LGM times by Svitoch (2003) and Chepalyga (2007).

Thus, there is no clear understanding regarding the source of such additional water 15 volume. To fill the transgressive Khvalynian Basin, it was proposed that the CS catchment was enlarged by the Valdai ice sheet in the north. Kvasov (1979) proposed that glacial damming caused overflow of northern rivers (Vychegda, Mezen', and Pechora) to the Kama River and the Upper Dnieper River to the Oka River and consequently to the Volga basin and the CS. However, it was recently found that the Late Valdai (Late

Vistulian) ice sheet did not cover the north-east EEP, and therefore, most of the northern rivers were not dammed at that time (Mangerud et al., 2004). In the Upper Dnieper River valley, distinct traces of melt-water runoff are found instead of ice damming of the river (Sidorchuk et al., 2011). Consequently, ice-sheet damming and re-routing of river runoff could not have caused the Khvalynian transgression. However, Kvasov (1979) also suggested that a large portion of the ice sheet discharged its melting waters directly to the Volga River. This idea will be discussed below in this section.

Parameters of the Eurasian North ice sheet (Svendsen et al., 2004) were used to calculate the volume of glacial meltwater that could be most likely joined to the Volga River runoff. A layer of meltwater is expressed as follows: $h_{\mathrm{mw}}=W / \rho L_{\mathrm{c}}$, where $L_{\mathrm{c}}$ is
$8,5053-5081,2012$

\section{Palaeostages of the Caspian Sea as a set of regional benschmark tests}

A. Kislov et al.

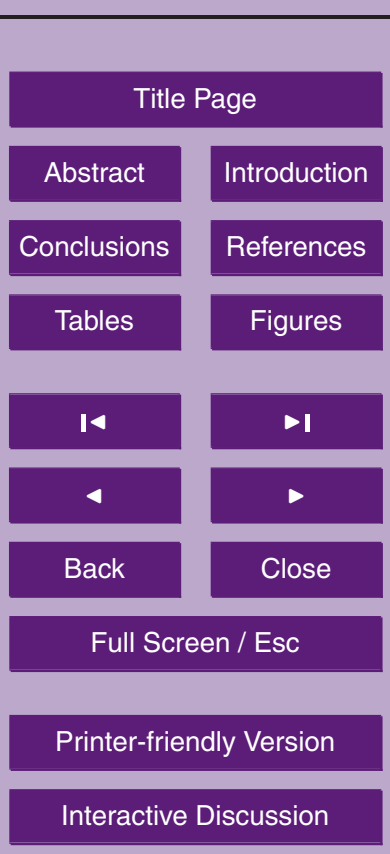


the latent heat of snow and ice melting, $\rho$ is density and $W$ is a heat flux. The heat flux was estimated based on the data from the cnrn PMIP2 experiment.

It was recognised that melt-water discharge during the warm season provides a large contribution to the Volga River runoff volume. This contribution reached $\sim 460 \mathrm{~km}^{3} \mathrm{yr}^{-1}$, 5 which is almost twice as much as the modern value of runoff. This additional water inflow could raise the CS level to approximately $45-50 \mathrm{~m}$ compared to the modern point (see Fig. 1).

Two challenges should be addressed before this result is taken as the physical basis for understanding the origin of the CS Khvalynian transgression (last stage). First, the 10 above value of glacio-fluvial contribution was obtained under the assumption that all of the melting water from the sector of the ice sheet was trapped by the Volga River. The delimitation of the glacial part of the catchment (see white dotted line on Fig. 7) is produced from isolines of the ice-sheet surface, which inevitably simplifies the spatial pattern of melt-water drainage. For example, this approach does not account for the 15 potential diversion of water to subglacial and marginal channels. The above value $(\sim$ $460 \mathrm{~km}^{3} \mathrm{yr}^{-1}$ ) should therefore be considered as a rough upper-limit estimation only. Secondly, the ice sheet covered only a narrow strip of the Volga catchment (see Fig. 7). Therefore, glacial melt waters could reach the Volga River only around the maximal stage of the LGM. At the same time, most researchers regard the CS levels during the LGM as having been very low (in the Atelian or Enotaevkian regression stage,

according to different authors). The Early Khvalynian level rise is dated to pre-LGM or post-LGM times when the configuration of the ice sheet did not permit any meltwater supply to the CS catchment. Consequently, the potential supply of melt water and sea-level rise does not coincide in time, making this hypothesis untenable.

\section{5}




\section{Conclusions}

This paper describes the temporal behaviour of the CS, the origin of its transgressive and regressive stages, and the relationship between sea level and climate based on the links between sea-level variations and the water budget.

5 Water-budget changes over the EEP are determined by the fluctuations in precipitation over large parts of the EEP. Therefore, climate models could be validated based on how well they reproduce the CS level changes and the current CS level changes can be used as a benchmark test. Unfortunately, the studied models (miroc, giss and cnrn) showed that the simulated current decadal variations are too small to reproduce 10 the observed CS level changes.

The extremely low level of the CS during the LGM has been reconstructed. The lowered level of the Caspian Sea in the LGM is well simulated by the studied models as a response to the Late Quaternary glacial/cooling/drying planetary conditions. Therefore, climate models could be verified based on how well they reproduce the low-level CS 15 phenomenon during the LGM. Moreover, it was established that such changes primarily reflect anomalies of the Volga River runoff. The same mechanism must be realised within the models, and this effect should be checked.

During the mid-Holocene, the CS level varied around its modern position with an amplitude of several meters. The absence of long data integrations does not permit conclusions about the origins of such oscillation and the possibility of their reproduction. Using these data as a benchmark test is problematic.

Using parameters of the highest (Khvalynian) CS transgression as a benchmark test is also problematic. Estimations based on palaeochannel dimensions indicate a twofold increase of runoff from the Caspian Sea catchment during the Late Glacial 25 time period, which is sufficient to explain the Khvalynian sea-level rise. In contrast, the river runoff values simulated using climate models do not increase to the extent needed for such a high CS level rise. This discrepancy needs further explanation to produce more reliable palaeohydrological estimations both from empirical data and
8, 5053-5081, 2012

\section{Palaeostages of the Caspian Sea as a set of regional benschmark tests}

A. Kislov et al.




from mathematical modelling. One of the issues is the incorporation of glacial meltwater into the CS palaeoclimate water balance.

Therefore, only well-established and well-quantified deep regression stages of the Caspian Sea during the peak of the LGM can be used as regional benchmark tests for 5 current climate models as a measure of the assessment of the water budget over the EEP. Additionally, the fact that this event was determined by a decrease of the Volga River runoff can be used as a test.

Acknowledgements. Acknowledgements. The authors would like to thank the Russian Foundation for Basic Research (grant 10-05-00434-a) for financial support. We thank A. Paul for his 10 very helpful and supportive comments.

\section{References}

Allen, A., Jackson, J., and Walker, R.: Late Cenozoic reorganisation of the Arabia-Eurasia collision and the comparison of the short-term and long-term deformation rates, Tectonics, 23, TC 2008, 2004.

15 Arpe, K. and Leroy, S.: The Caspian Sea Level forced by the atmospheric circulation, as observed and modeled, Quatern. Int., 173-174, 144-152, 2007.

Arpe, K., Leroy, S. A. G., Lahijani, H., and Khan, V.: Impact of the European Russia drought in 2010 on the Caspian Sea level, Hydrol. Earth Syst. Sci., 16, 19-27, doi:10.5194/hess-1619-2012, 2012.

Bezrodnykh, Yu. P., Romanyuk, B. F., Deliya, S. V., Magomedov, R. D., Sorokin, V. M., Parunin, O. B., and Babak, E. V.: Biostratigraphy and structure of the Upper Quaternary deposits and some paleogeographic features of the north Caspian region, Stratigr. Geo. Correl., 12, 102-111, 2004.

Chepalyga, A.: The Late Glacial Great Flood in the Ponto-Caspian basin, in: Book on "The Black Sea Flood Question: Changes in: Coastline, Climate, and Human Settlement", edited by: Yanko-Hombach, V., Gilbert, A. S., Panin, N., and Dolukhanov, P. M., Springer, 119-148, 2007.

Golitsyn, G. S. and Panin, G. N.: The water balance and modern variations of the level of the Caspian Sea, Soviet Meteorololgy and Hydrology (English Translation), 1, 46-52, 1989.
$8,5053-5081,2012$

\section{Palaeostages of the Caspian Sea as a set of regional benschmark tests}

A. Kislov et al.

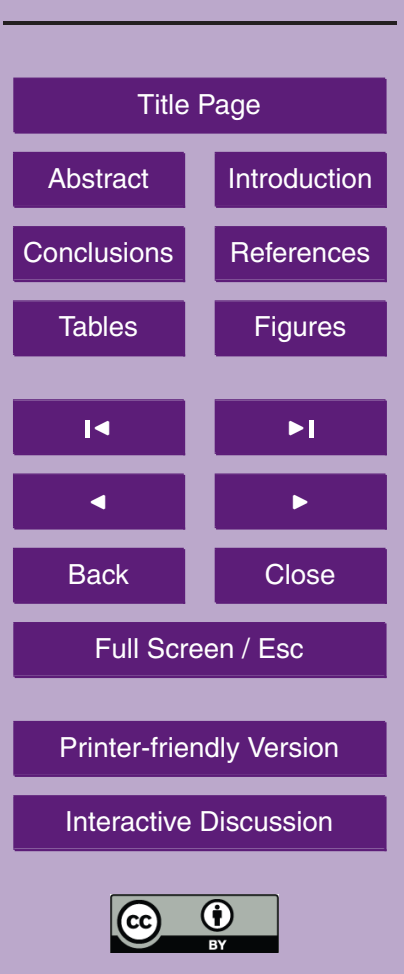


Golitsyn, G. S., Ratkovich, D., Fortus, M., and Frolov, A. V.: Current rise of the Caspian sea level, Water Resour. (English Translation), 25, 133-139, 1998.

Kaplin, P. A. and Selivanov, A. O.: Recent coastal evolution of the Caspian sea as a natural model for coastal responses to the possible acceleration of global sea-level rise, Mar. Geol., 124, 161-175, 1995.

Kislov, A. V. and Toropov, P. A.: Modeling of Variations in River Runoff on the East European Plain under Different Climates of the Past, Water Resour. (English Translation), 33, 471-482, 2006.

Kislov, A. V. and Toropov, P. A.: Climate modeling results for the circum-Pontic region from the late Pleistocene to the mid-Holocene, in: Book on "The Black Sea Flood Question: Changes in Coastline, Climate, and Human Settlement", edited by: Yanko-Hombach, V., Gilbert, A. S., Panin, N., and Dolukhanov, P. M., Springer, 47-62, 2007.

Kislov, A. and Toropov, P.: Modeling extreme Black Sea and Caspian Sea levels of the past 21,000 years with general circulation models, in: Geology and Geoarchaeology of the Black Sea Region: Beyond the Flood Hypothesis, edited by: Buynevich, I. V., Yanko-Hombach, V., Gilbert, A. S., and Martin, R. E., Geological Society of America, Special Paper 473, 27-32, 2011.

Kroonenberg, S. B., Abdurakhmanov, G. M., Badyukova, E. N., van der Borg, K., Kalashnikov, A., Kasimov, N. S., Rychagov, G. I., Svitoch, A. A., Vonhof, H. B., and Wesselingh, F. P.: Solar-forced 2600 BP and Little Ice Age highstands of the Caspian Sea, Quatern. Int., 173, 137-143, 2007.

Kroonenberg, S. B., Kasimov, N. S., and Lychagin, M. Yu.: The Caspian Sea: A natural laboratory for sea-level change, Geography, Environment, Sustainability, 1, 22-37, 2008.

Kvasov, D. D.: The Late Quaternary history of large lakes and inland seas of Eastern Europe, Annales Academiae Scientarum Fennicae, ser. A III. Helsinki, 127, 1979.

Mangerud, J., Jakobsson, M., Alexanderson, H., Astakhov V., Clarke, G. K. C., Henriksen, M., Hjort, C., Krinner, G., Lunkka, J. P., Möller, P., Murray, A., Nikolskaya, O., Saarnisto, M., and Svendsen, J. I.: Ice-dammed lakes and rerouting of the drainage of northern Eurasia during the Last Glaciation, Quaternary Sci. Rev., 23, 1313-1332, 2004.

30 Mikhailov, V. N. and Povalishnikova, E. S.: Once more on the causes of the Caspian Sea level fluctuations during the 20th century, Bulletin of Moscow State University, Ser.5, 3, 35-38, 1998 (in Russian).
8, 5053-5081, 2012

\section{Palaeostages of the \\ Caspian Sea as a set of regional \\ benschmark tests}

A. Kislov et al.

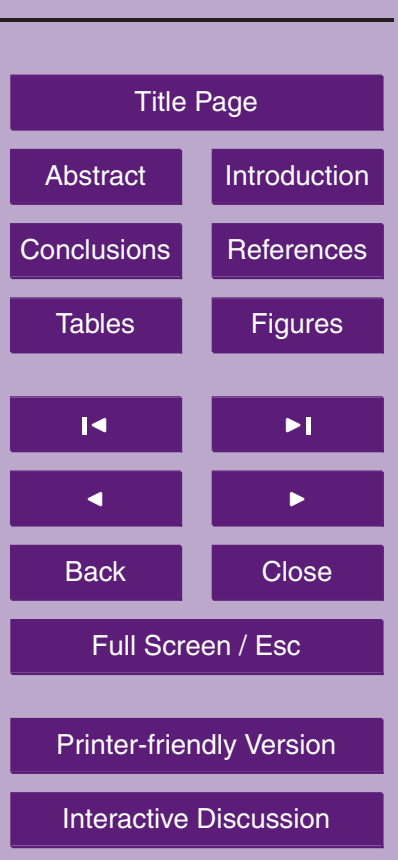


Panin, A. V. and Selezneva, E. V.: Palaeoestimations of the Caspian Sea water balance based on new hypsometric curve: Current problems of geomorphology, theory and practice in study of geomorphic systems. Part 1, Astrakhan, Technograd Publ. 77-82, 2011 (in Russian).

Panin, A. V. and Sidorchuk, A. Yu.: Macromeanders ("large meander"): Problems of origin and interpretation, Bulletin of Moscow State University, Ser. 5, 6, 14-22, 2006 (in Russian).

Rodionov, S. N.: Global and Regional Climate Interaction: The Caspian Sea Experience, Kluwer Academic Publications, 241, 1994.

Rychagov, G. I.: History of the Caspian Sea in the Pleistocene, Moscow Univ. Publ., 266, 1997a (in Russian).

10 Rychagov, G. I.: Holocene oscillations of the Caspian Sea, and forecasts based on palaeogeographical reconstructions, Quatern. Int., 41/42, 167-172, 1997b.

Schmidt, G. A., Ruedy, R., Hansen, J. E., Aleinov, I., Bell, N., Bauer, M., Bauer, S., Cairns, B., Canuto, V., Cheng, Y., Del Genio, A., Faluvegi, G., Friend, A. D., Hall, T. M., Hu, Y., Kelley, M., Kiang, N. Y., Koch, D., Lacis, A. A., Lerner, J., Lo, K. K., Miller, R. L., Nazarenko, L., Oinas, V., Perlwitz, Ja., Perlwitz, Ju., Rind, D., Romanou, A., Russell, G. L.,. Sato, Mki, Shindell, D. T., Stone, P. H., Sun, S., Tausnev, N., Thresher,D., and Yao, M.-S.: Present day atmospheric simulations using GISS ModelE: Comparison to in-situ, satellite and reanalysis data, J. Climate, 19, 153-192, 2006.

Sidorchuk, A., Panin, A., and Borisova, O.: Morphology of river channels and surface runoff in the Volga River basin (East European Plain) during the Late Glacial period, Geomorphology, 113, 137-157, 2009.

Sidorchuk, A., Panin, A., and Borisova, O.: Surface runoff to the Black Sea from the East European Plain during Last Glacial Maximum-Late Glacial time, in: Geology and Geoarchaeology of the Black Sea Region: Beyond the Flood Hypothesis, edited by: Buynevich, I. V., YankoHombach, V., Gilbert, A. S., and Martin, R. E., Geological Society of America Special Paper 473, 1-25, 2011.

Sorokin, V. M.: Correlation of upper quaternary deposits and paleogeography of the Black and Caspian seas, Stratigr. Geo. Correl., 19, 563-578, 2008.

Svendsen, J. I., Alexanderson, H., Astakhov, V. I., Demidov, I., Dowdeswell, J. A., Funder, S., Gataullin, V., Henriksen, M., Hjort, C., Houmark-Nielsen, M., Hubberten, H. W., Ingólfsson, O., Jakobsson, M., Kjar, K. H., Larsen, E., Lokrantz, H., Lunkka, J. P., Lysa, A., Mangerud, J., Matiouchkov, A., Murray, A., Moller, P., Niessen, F., Nikolskaya, O., Polyak, L., Saarnisto,
8, 5053-5081, 2012

\section{Palaeostages of the \\ Caspian Sea as a set of regional benschmark tests}

A. Kislov et al.

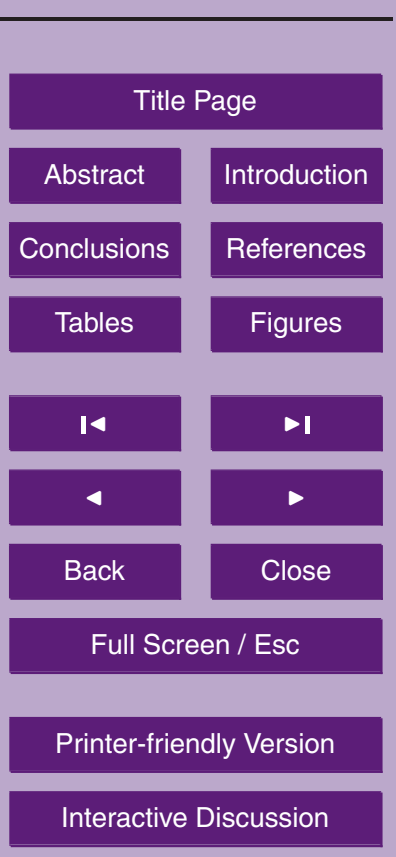


M., Siegert, C., Siegert, M. J., Spielhagen, R. F., and Stein, R.: Late Quaternary ice sheet history of northern Eurasia, Quaternary Sci. Rev., 23, 1229-1271, 2004.

Svitoch, A.: Marine Pleistocene of the Russian Coasts, GEOS, 362, 2003 (in Russian).

Varuschenko, S. I., Varuschenko, A. N., and Klige, R. K.: Changing regime of the Caspian Sea and closed lakes in paleotime, Moscow, Nauka Publ., 238 p., 1987 (in Russian).

Voldoire, A., Sanchez-Gomez, E., Salas y Mélia, D., Decharme, B., Cassou, C., Sénési, S., Valcke, S., Beau, I., Alias, A., Chevallier, M., Déqué, M., Deshayes, J., Douville, H., Fernandez, E., Madec, G., Maisonnave, E., Moine, M.-P., Planton, S., Saint-Martin, D., Szopa, S., Tyteca, S., Alkama, R., Belamari, S., Braun, A., Coquart, L., and Chauvin, F.: The CNRM-CM5.1 global climate model: Description and basic evaluation, Clim. Dynam., doi:10.1007/s00382011-1259-y, in press, 2012.

Watanabe, S., Hajima, T., Sudo, K., Nagashima, T., Takemura, T., Okajima, H., Nozawa, T., Kawase, H., Abe, M., Yokohata, T., Ise, T., Sato, H., Kato, E., Takata, K., Emori, S., and Kawamiya, M.: MIROC-ESM 2010: model description and basic results of CMIP5-20 cm ex-

\section{$8,5053-5081,2012$}

\section{Palaeostages of the Caspian Sea as a set of regional benschmark tests}

A. Kislov et al.

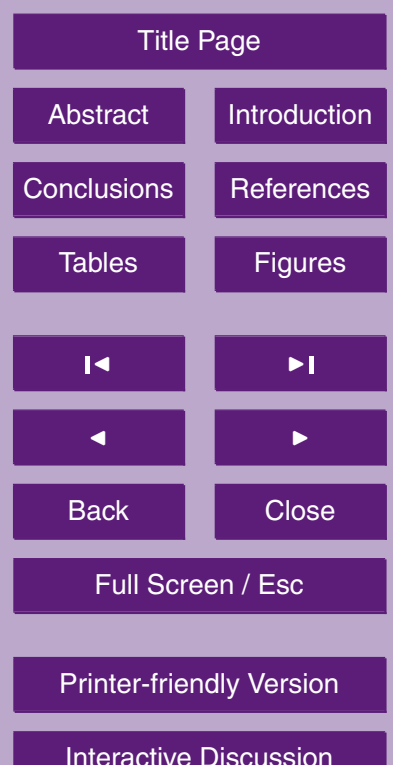

Interactive Discussion 
Table 1. Major stages of the Caspian Sea in the Late Pleistocene - the Holocene

\begin{tabular}{|c|c|c|c|c|c|}
\hline & Stage & & pian Sea level & Age & (ka BP) \\
\hline $\mathrm{R} / \mathrm{T}^{*}$ & Name & a.s.I., $\mathrm{m}$ & relative to modern stage, $\mathrm{m}$ & older estimation & younger estimation \\
\hline $\mathrm{R}$ & Atelian & $-60^{2}-70^{5}$ & $-30-40$ & $75-85^{1,2,9}$ & $20-23^{4,6}$ \\
\hline $\mathrm{T}$ & Early Khvalynian & $+48^{1-9}$ & +75 & $50-70^{1,2}$ & $\begin{array}{l}25-35^{5,9} \\
13-18^{4,6}\end{array}$ \\
\hline $\mathrm{R}$ & Enotaevkian & $-40^{2}-47^{5}-64^{1}$ & $-13-20-37$ & $\begin{array}{c}35^{2} \\
20-25^{1}\end{array}$ & $\begin{array}{c}19-20^{5} \\
10-10.5^{4}\end{array}$ \\
\hline $\mathrm{T}$ & Late Khvalynian & $0^{1-9}$ & +27 & $\begin{array}{c}19^{2} \\
10-18^{5} \\
\mathbf{1 4 - 1 8 ^ { 1 }}\end{array}$ & $9^{4}$ \\
\hline $\mathrm{R}$ & Mangyshlakian & $-50^{1,2}-36$ & $-23-9$ & $12^{2}$ & $8^{4}$ \\
\hline $\mathrm{T}$ & $\begin{array}{l}\text { New-Caspian } \\
\text { (2nd phase, } \\
\text { highest stand) }\end{array}$ & $-20^{3}$ & +7 & $9^{1}$ & $8^{3}$ \\
\hline $\mathrm{R}$ & Makhachkalanian & $-40^{1}<-28^{3}$ & $-13<-1$ & & $7^{3}$ \\
\hline $\mathrm{T}$ & New-Caspian (4th phase) & $-22^{3}-23^{1}$ & $+4+5$ & $3-3.5^{3}$ & $2.6^{7,8}$ \\
\hline $\mathrm{R}$ & Derbentian & $-34^{1,3}-45^{8}$ & $-18-7$ & $1-2^{3}$ & $\begin{array}{c}1-1.5^{8} \\
0.7-1.6^{1}\end{array}$ \\
\hline $\mathrm{T}$ & $\begin{array}{l}\text { New-Caspian } \\
\text { (5th phase, } \\
\text { the LIA highstand) }\end{array}$ & $-25^{3}$ & +2 & & $0.3-0.6^{3,7,8}$ \\
\hline & Current stage & $-27 \pm 0.5$ & 0 & & modern \\
\hline
\end{tabular}

Notes:

Most probable dates from the authors' view are shown in bold.

${ }^{*} \mathrm{R}$ - regression (lowstand), $\mathrm{T}$ - transgression (highstand)

Sources: ${ }^{1}$ Varuschenko et al. (1987), ${ }^{2}$ Rychagov (1997a), ${ }^{3}$ Rychagov (1997b), ${ }^{4}$ Svitoch (2003), ${ }^{5}$ Bezrodnykh et al. (2004), ${ }^{6}$ Chepalyga (2007), ${ }^{7}$ Kroonenberg et al. (2007), ${ }^{8}$ Kroonenberg et al. (2008), ${ }^{9}$ Sorokin (2011).
$8,5053-5081,2012$

\section{Palaeostages of the Caspian Sea as a set of regional benschmark tests}

A. Kislov et al.

Title Page

\begin{tabular}{c|c|}
\hline Abstract & Introduction \\
\hline Conclusions & References \\
\hline Tables & Figures \\
\hline I4 & -1 \\
\hline 4 & - \\
\hline Back & Close \\
\hline
\end{tabular}

Full Screen / Esc

Printer-friendly Version

Interactive Discussion 


\section{Palaeostages of the Caspian Sea as a set of regional benschmark tests}

A. Kislov et al.

Table 2. Time-averaged annual sum of precipitation $(P)$ and evaporation $(E)$ over the Volga River catchment area and the Volga River runoff $(Y)$ during modern climate (miroc_00) and the LGM (miroc_21BP).

\begin{tabular}{lrrr}
\hline experiment & $P, \mathrm{~mm}$ & $E, \mathrm{~mm}$ & $Y, \mathrm{~mm}$ \\
\hline miroc_00 & 633 & 427 & 206 \\
miroc_21BP & 291 & 154 & 137 \\
anomaly & $-53 \%$ & $-64 \%$ & $-33 \%$ \\
\hline
\end{tabular}

Title Page

Abstract

Conclusions

Tables

14

4

Back

Full Screen / Esc

Printer-friendly Version

Interactive Discussion 


\section{Palaeostages of the Caspian Sea as a set of regional benschmark tests}

A. Kislov et al.

Table 3. Time-averaged annual sum of precipitation $(P)$ and evaporation $(E)$ over the Volga River catchment area and the Volga River runoff $(Y)$ during modern climate (miroc_00) and the Mid-Holocene (miroc_6BP).

\begin{tabular}{lrrr}
\hline experiment & $P, \mathrm{~mm}$ & $E, \mathrm{~mm}$ & $Y, \mathrm{~mm}$ \\
\hline miroc_00 & 633 & 427 & 206 \\
miroc_6BP & 621 & 416 & 205 \\
anomaly & $-2 \%$ & $-3 \%$ & $-1 \%$ \\
\hline
\end{tabular}

Title Page

Abstract

Conclusions

Tables

14

4

\section{Back}

Introduction

References

\section{Figures}

Full Screen / Esc

Printer-friendly Version

Interactive Discussion 


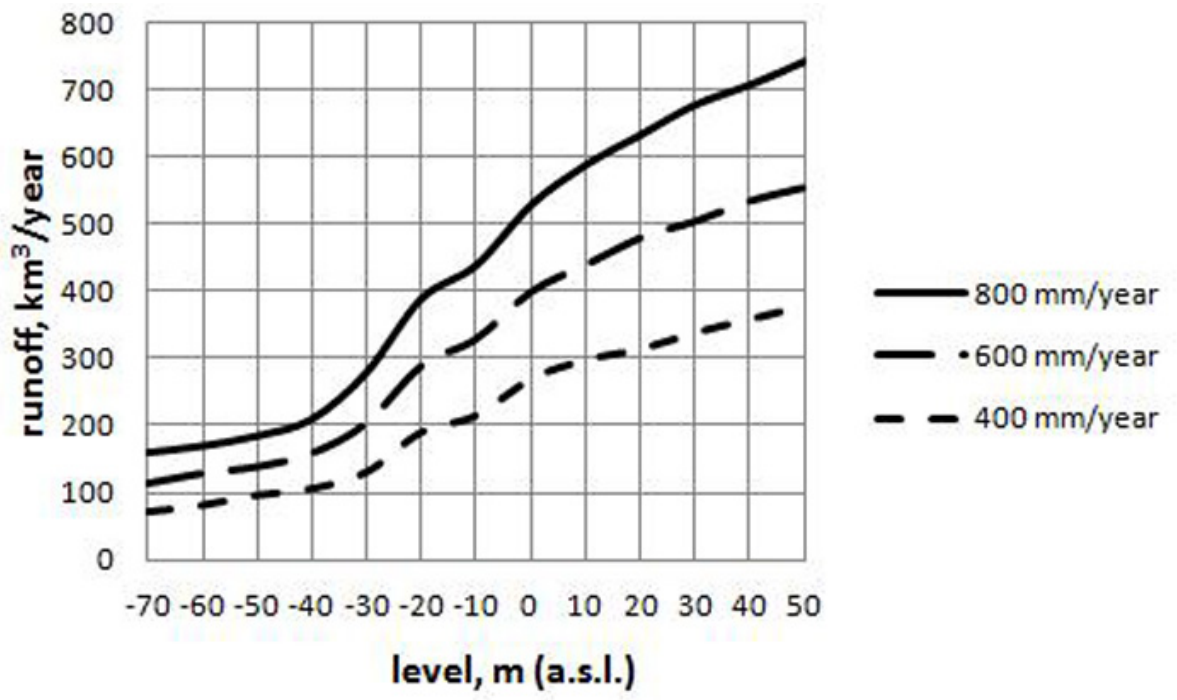

Fig. 1. The Caspian Sea level (steady-state condition) depending on the balance of "precipitation minus evaporation" over the sea surface $\left(\mathrm{mm} \mathrm{yr}^{-1}\right)$ and runoff volume.
$8,5053-5081,2012$

\section{Palaeostages of the Caspian Sea as a set of regional benschmark tests}

A. Kislov et al.

\section{Title Page}

Abstract Introduction

Conclusions

References

Tables Figures

14

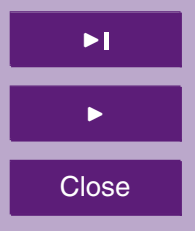

Back

lose

Full Screen / Esc

Printer-friendly Version

Interactive Discussion 


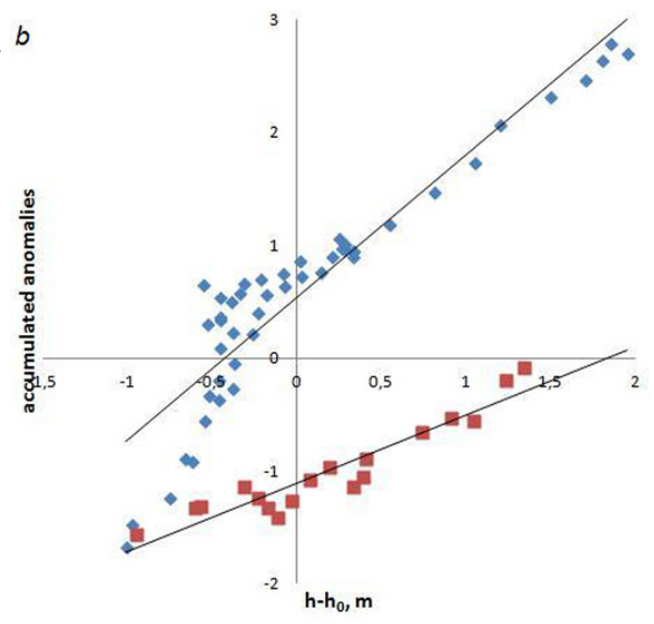

Fig. 2. The cumulative curve of the observed Volga River runoff variations and changes of the Caspian Sea level (a) and relationships (b) of the accumulated runoff anomalies and the Caspian Sea level changes for the years 1931-1977 (blue rhombus) and 1978-1995 (red squares); the correlation coefficients are 0.93 and 0.94 , respectively.

8, 5053-5081, 2012

\section{Palaeostages of the Caspian Sea as a set of regional benschmark tests}

A. Kislov et al.

Title Page

Abstract

Conclusions

Tables

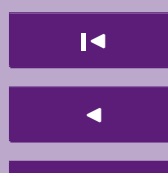

Back
Introduction

References

Figures

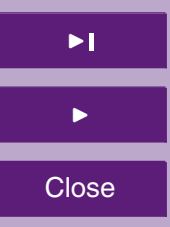

Full Screen / Esc

Printer-friendly Version

Interactive Discussion 


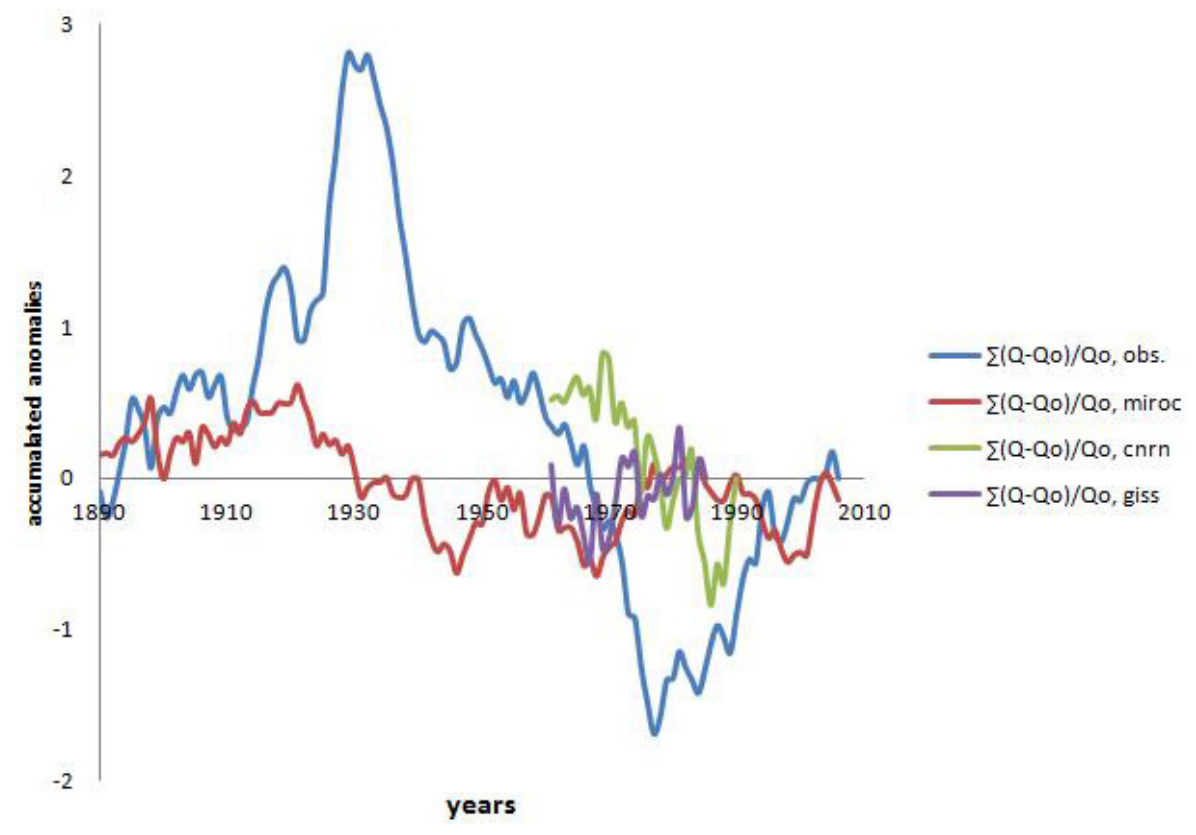

Fig. 3. Cumulative curves of the observed (partly the same as in Fig. 2a) and simulated Volga River runoff variations.
8, 5053-5081, 2012

\section{Palaeostages of the Caspian Sea as a set of regional benschmark tests}

A. Kislov et al.

Title Page

Abstract Introduction

Conclusions

References

Tables Figures

14

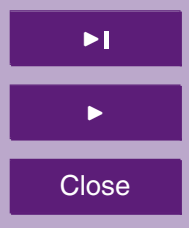

Back

Full Screen / Esc

Printer-friendly Version

Interactive Discussion 


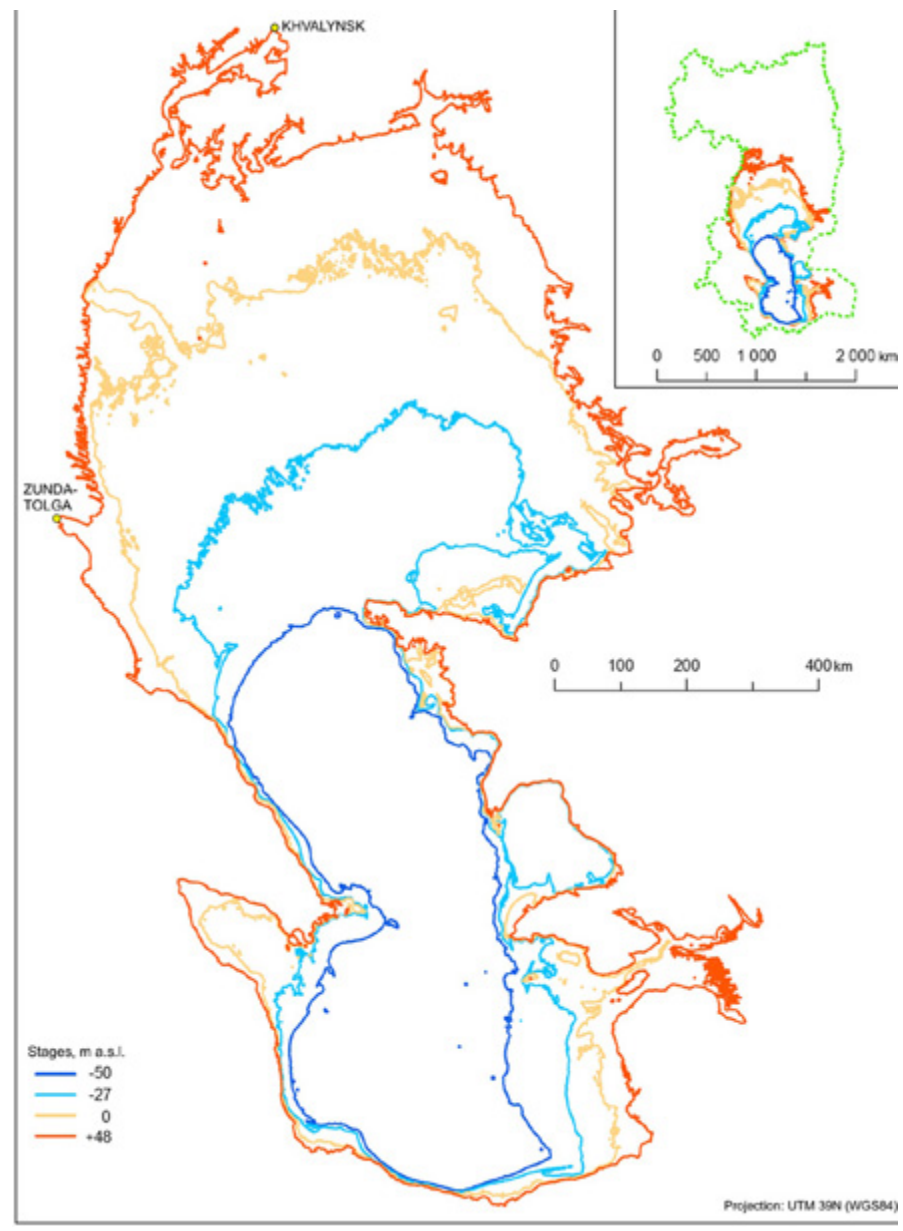

8, 5053-5081, 2012

\section{Palaeostages of the} Caspian Sea as a set of regional benschmark tests

A. Kislov et al.

Title Page

Abstract Introduction

Conclusions

References

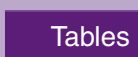

Figures
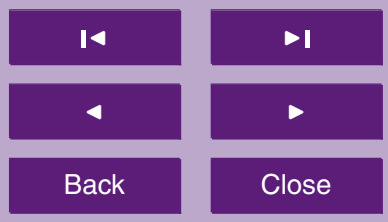

Back

Full Screen / Esc

Printer-friendly Version

Interactive Discussion

Fig. 4. (Caption on next page.) 
Fig. 4. Changes of the Caspian Sea area in the end of the Late Pleistocene. The inset shows the modern Caspian Sea catchment. Stages (a.s.l.) and events in the chronological scenario accepted by the authors (see Table 1):

$-50 \mathrm{~m}=$ representative of the Enotaevkian (LGM) and

Mangyshlakian (Younger Dryas) regression stages;

$-27 \mathrm{~m}=$ the modern basin;

$0 \mathrm{~m}=$ the Late Khvalynian transgressive stage (the Lateglacial time, end of MIS 2);

$+48 \mathrm{~m}=$ the Early Khvalynian transgressive stage (end of MIS 3).

Khvalynsk town denotes the limit of the northernmost penetration of the Early Khvalynian waters via the Volga River valley. Zunda Tolga village is the location of the modern Manych sill at +26 m a.s.l. that has been limiting the Caspian Sea overflow since the end of the Early Khvalynian transgression.

The map was produced by E. V. Selezneva using the GRASS GIS 6.4.1 package. The CS bathymetry was taken from the GEBCO (General Bathymetric Chart of the Oceans) model, which has $30^{\prime \prime}$ spatial resolution and a $1 \mathrm{~m}$ depth increment. The land topography was taken from the SRTM3 (Shuttle Radar Topographic Mission) with $3^{\prime \prime}$ spatial resolution and $1 \mathrm{~m}$ increments in altitude. The two models were joined into one DEM with a spatial resolution of $3^{\prime \prime}$.
$8,5053-5081,2012$

\section{Palaeostages of the Caspian Sea as a set of regional benschmark tests}

A. Kislov et al.

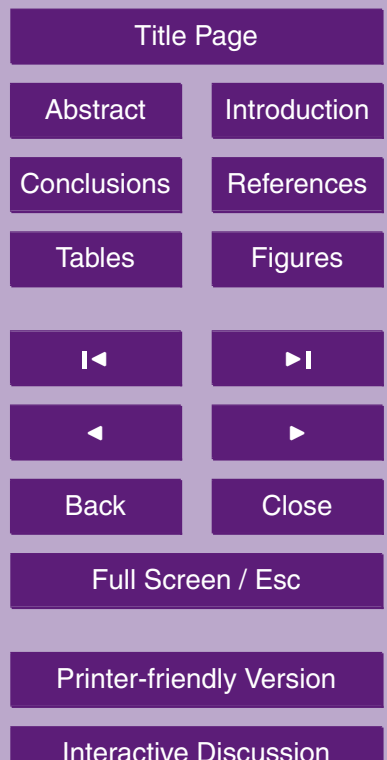

Interactive Discussion 


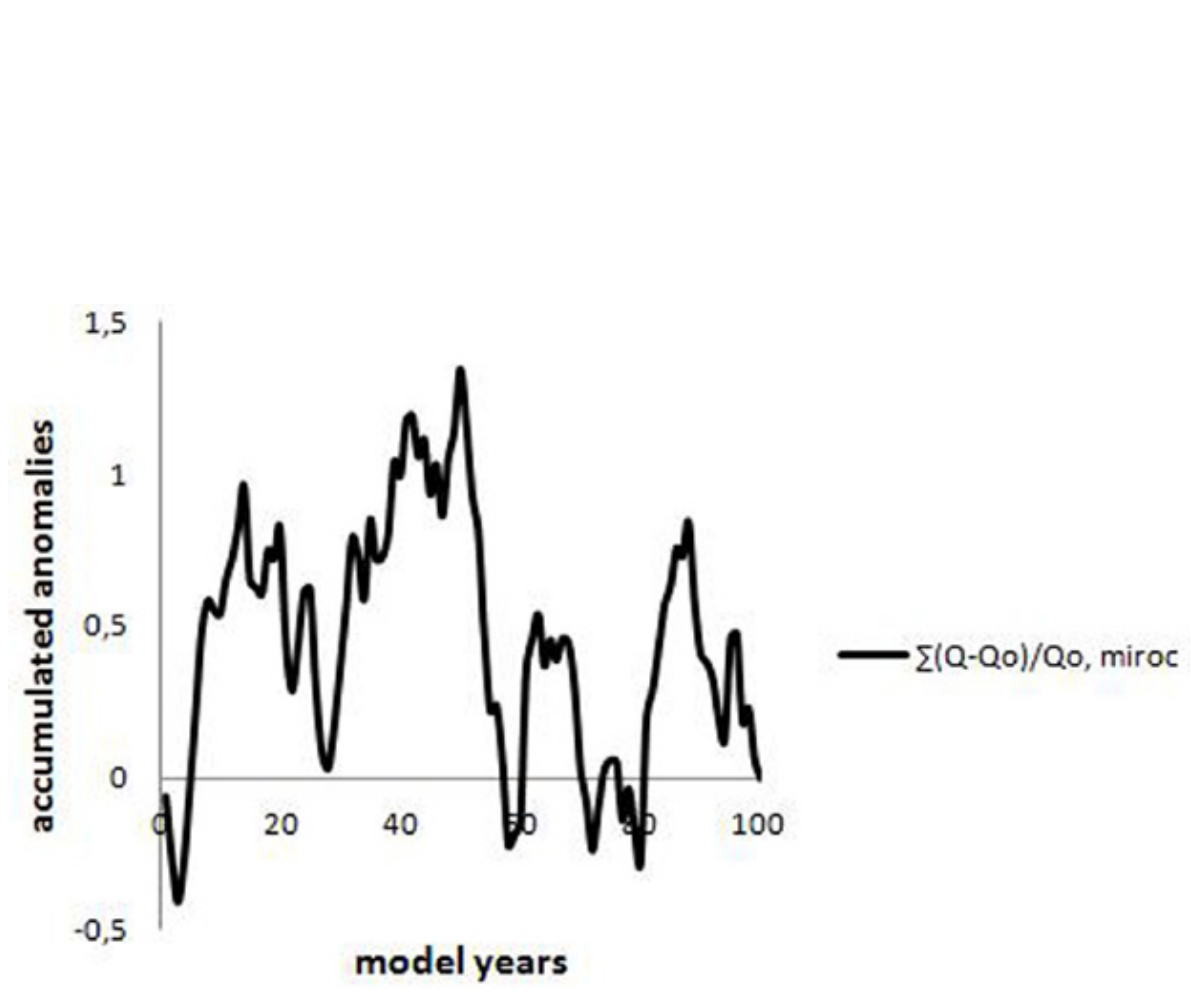

Fig. 5. Cumulative curve of the simulated (using the miroc model) Volga River runoff variations during $100 \mathrm{yr}$ of LGM conditions.

Palaeostages of the Caspian Sea as a set of regional benschmark tests

A. Kislov et al.

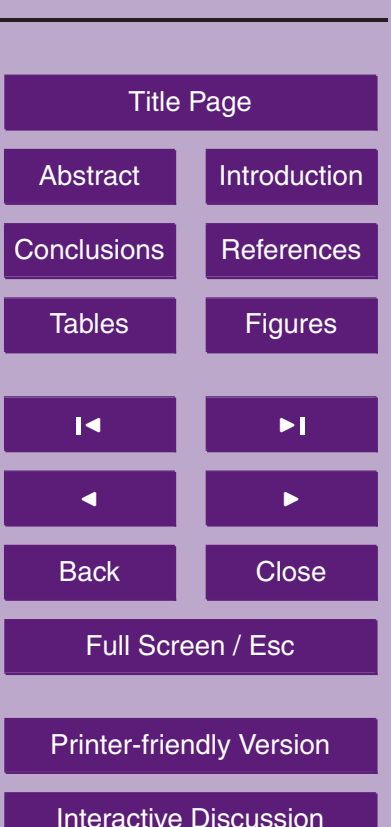

Interactive Discussion 


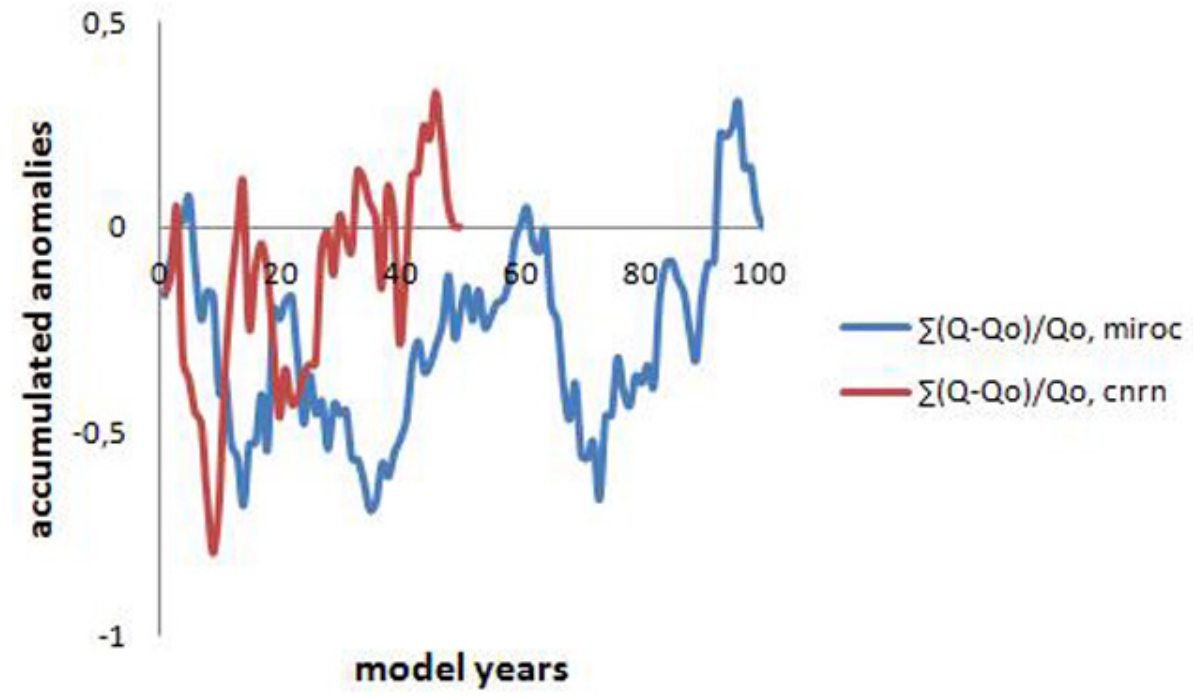

Fig. 6. Cumulative curves of the simulated (using the miroc and cnrn models) Volga River runoff variations during 100 and $50 \mathrm{yr}$, respectively, of Mid-Holocene conditions.

$8,5053-5081,2012$

Palaeostages of the Caspian Sea as a set of regional benschmark tests

A. Kislov et al.

Title Page

Abstract Introduction

Conclusions

References

Tables

Figures

14

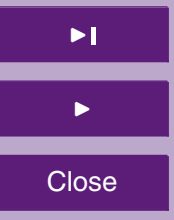

Back

Full Screen / Esc

Printer-friendly Version

Interactive Discussion 


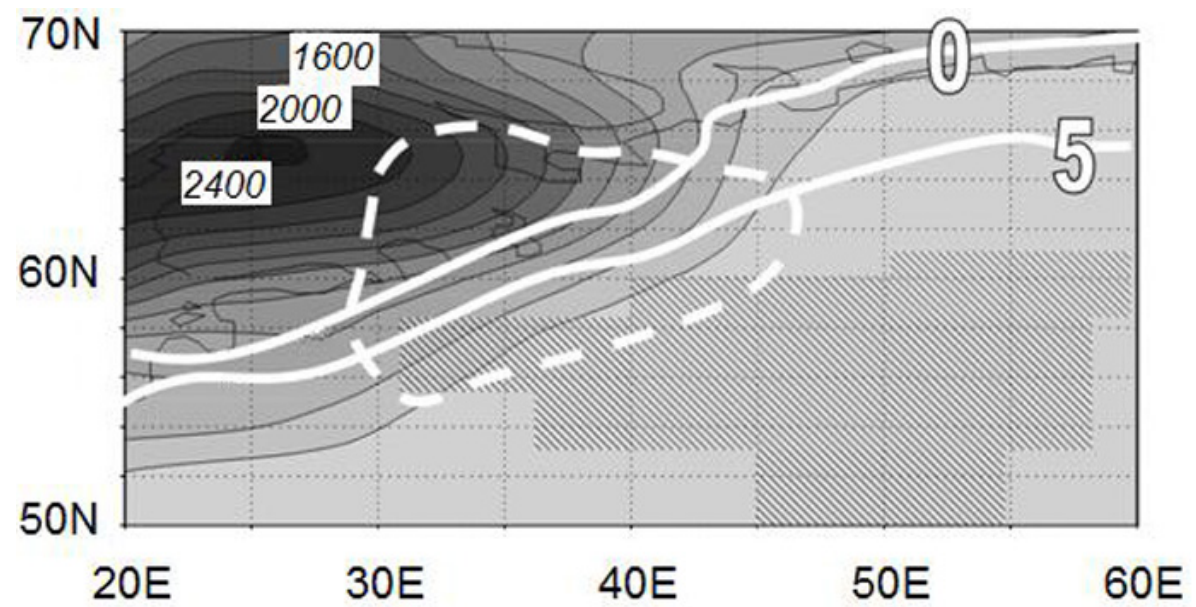

Fig. 7. Scandinavian ice sheet in the northern European part of Russia (dark lines = isohypses of the ice surface) and the northern part of the Volga River catchment area (shading area). The white dotted line depicts the part of the glacier from which meltwater could flow into the Volga River catchment area. The bold white lines are the isotherms of July.
8, 5053-5081, 2012

\section{Palaeostages of the Caspian Sea as a set of regional benschmark tests}

A. Kislov et al.

\section{Title Page}

Abstract

Conclusions

Tables

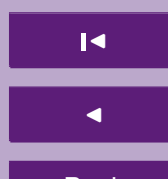

Back
References

Figures

Full Screen / Esc

Printer-friendly Version

Interactive Discussion 